\title{
The methodological strategy of architectonics of multicultural education in the postmodern era
}

Streszczenie: Celem artykułu jest próba interpretacji nowego pluralistycznego typu cywilizacji oraz właściwości współczesnego społeczeństwa wielokulturowego w kontekście przestrzeni edukacyjnej. Na gruncie tego zaproponowano zastąpienie pojęcia edukacji wielokulturowej terminem edukacji polietnicznej, która skierowana jest na harmonizację wzajemnego stosunku między etnicznymi lub narodowymi społeczeństwami, a w ich granicach - między różnymi grupami społeczno-kulturowymi, mającymi różną identyczność kulturową (polityczną, regionalną, płciową, religijną, wiekową, profesjonalną i in.). Zaproponowano i uzasadniono nową architektonikę edukacji wielokulturowej, w centrum której znajduje się życiowy paradygmat jednostki. W związku z tym udowadnia się pięć najważniejszych strategii metodologicznych edukacji wielokulturowej, które są jej punktem orientacyjnym oraz źródłem życiowym.

W artykule zostały także zarysowane problemy implementacji projektu edukacji wielo-kulturowej na Ukrainie, które utrudniają harmonizację życia społecznego oraz procesy dialogu międzykulturowego i porozumiewania się.

Słowa kluczowe: multikulturalizm, edukacja wielokulturowa, identyczność, globalna lokalność, pamięć historyczno-kulturalna, kulturowo-etniczny narcyzm, polityka demokratyczno-egalitarna

The problem of intercultural interaction has become a focus for politicians, philosophers, specialists in cultural studies as well as for a wide pedagogical community. Many educationalists anxiously confirm the growth of nationalist sentiments, especially among ethnic minorities. They see the manifestation of this ethno-centrism in hostility of indigenous minorities both towards dominant ethnic groups and towards new migrant subcultures. Its sources are found in the consequences of educational assimilation and the "cultural genocide" of ethnic minorities. In this regard, the necessity for multicultural education and training in many countries becomes a strategy of great significance. This position is traced in numerous documents of the United 
Nations Organization, UNESCO, the Council of Europe, in which it is emphasized that one of the most important functions of modern education is to teach people to live together, to help them to transform the growing interdependence of countries and ethnic groups into conscious solidarity. For this purpose, education should help to ensure that, on one hand, people have become aware of their roots and thus can determine their actual place in the world, but, on the other hand, it should foster respect for other cultures. In the 1970-s, what appeared in the western intellectual culture was the concept of "multicultural education", which is defined in the context of educational studies as "... the educational process in which two or more cultures distinguished by linguistic, ethnic, national, or racial features are represented"1.

All this requires not just a new educational model, but also a clear demarcation of concepts in the context of modern multicultural society which is viewed in diversified political and theoretical (multicultural, postcolonial, communitarian, postmodern, etc.) discourse. Teaching to live in modern society does not only mean teaching how to skillfully navigate new databases, have large-scale information, and be knowledgeable and competent. It is crucial to transform all this into the wisdom of building life and the art of living as well as being considerate of "others".

\section{Features of modern multicultural society in the discourse of liberal theory}

The concepts of "multicultural society" and "pluricultural society" as those that are commonly used to characterize modern society, most likely should not absolutely be opposite to each other. Yet, pluricultural society can exist even without the policy of multiculturalism (for example, modern Russian society) as the policy of multiculturalism can be used against the interests and real needs of multicultural society. Moreover, modern multicultural society is connected not only with the problems of intercultural interaction of nations, races, and religions.

The new pluralistic type of civilization tries hard to avoid any enforcement of certain values, ideological guidelines or life strategies. Every individual builds their own identity model and comprehends and reproduces cultural

1 International Dictionary of Education. Vol. 7. Oxford 1994, Oxford University Press, p. 3963. 
meanings ${ }^{2}$. Being involved in transnational networks, an individual can no longer remain within their own national culture. Then, new local communities appear, separated by boundaries which do not always coincide with national borders. They unite people not by nationality, but by their common cultural preferences which go beyond any nation. V. Mezhuiev rightly states that "globalization creates a global locality, not a national one, and distinguishing between them depends on the cultural choice which is made" Thus, the centre of gravity now is not a certain ethnic or religious cultural group, but an individual as a liberal value that has freedom of choice.

There is a situation when the state loses the ability to control the 'purity' of the matrix of a single cultural model on its territory. Powerful international migration processes break the cultural landscape of modern countries (centres of Oriental medicine, belly dance studios, various restaurants with Oriental, African, and Latin American cuisine, Arabian coffee shops, martial arts, etc.). Under the influence of immigration, transformations occur in spiritual culture as well. Writers, composers, film directors, producers from immigrant environment go beyond a sustainable world view, deform and enrich it with new shades. This happens not without a massive demand for the uniqueness and endearment on the part of members of the 'titular' cultures. Even states with traditionally tough anti-immigration laws cannot resist this.

In modern multicultural countries, "ethnic actors", who previously had no chances to be noticed, now step on the stage of public life. Here, belonging to national minorities becomes a kind of value (the Tibetan culture in China, Scottish culture in the UK, Indian culture in North America, Basque culture in Spain, Tatar culture in Ukraine, etc.). Their common feature is the preservation of ethnic identity against the assimilation pressures from the state. No less powerful is also the ethnic opposition to national public cultural projects in separate regions. The so-called "regional identity" is formed (a Texan, a Catalan, a Siberian, a Silesian, a Donbas identity, etc.) as an important element of the construction of modern socio-cultural space. A region becomes a kind of brand in the global symbolic exchange, generating its own approaches to the issues of interaction with the neighbouring countries, global community, without resorting to national mediation. In other words,

2 P. Yu. Saukh: Suchasna osvita: portret bez prykras. Zhytomyr 2012, ZhDU im. I. Franka, p. 134.

3 V. Mezhuyev: Dialog yak sposib mizhkulturnogo spilkuvannya v suchasnomu sviti. “Filosofs'ka Dumka” 2011, No. 4, p. 98. 
"new regionalism" questions the existing classical symbolic borders, demonstrating an appeal of the local to the global, without the national.

The most characteristic feature of this situation is the cultural activity of absolutely new agents, who are not limited by national borders. They are transnational corporations whose activity is caused by the absence of the necessity of state mediation between an individual consumer of cultural products, on the one hand, and the manufacturers of these products, on the other ${ }^{4}$. Today there are the so called the complications of identity mechanisms. Now, civic and cultural "identification is carried out through consumption" , that is, it is not determined by ideological mobilization and political involvement but by "access to pleasure" 6 . A nation as a system-creating community, with which individuals traditionally identified themselves, seems blurred, ceasing to be a single cultural matrix. National identity now coexists with professional, sexual, religious, and regional identities. There is a trend to augment the identity communities which are formed on ideological as well as lifestyle grounds (feminism, pacifism, anarchism, the human rights movement etc.).

All the above-mentioned processes, being uncontrollable, form a global rather than national locality, the algorithm of which depends on the cultural choice of an individual. To describe this new type of cultural community, a well-known British sociologist Roland Robertson introduced a special term "glocalisation", which captures two interrelated processes in the modern world: homogenization and heterogenization. In its meaning, glocalisation is intended against those globalization concepts that are grounded on the theory of the formation of a unified world system of transnational connections and exclude any differences. Then, R. Robertson appropriately justifies the idea of the so-called cultural globalization which denies the possibility of full overcoming of cultural diversity in the world. Glocalisation does not suppress or undermine cultural diversity; instead, it preserves and even updates cultural localization, yet doing it not by national features but by various other features. In contrast to classical economic and sociological theories of globalisation, glocalisation tries to understand modern processes in the

4 V. Malakhov: Natsional'na derzhava, natsional'na kultura $i$ kulturniy suverenitet. "Filosofs'ka Dumka" 2011, No. 4, p. 125.

5 Zh. Bodriyar: Obshchestvo potrebleniya. Moskva 2006, "Respublika".

6 N. Stevenson: Globalization, national cultures and cultural citizenship. "Social. Quart." 1997, Vol. 38, No. 1, p. 41-66. 
concepts of the theory of culture. In a global world, the demand for culture cannot be limited by any national barriers; it is fully dictated by the needs and demands of an individual. The right of any individual to freedom of choice is a basic condition for the existence of culture globally. It is the only one that can ensure the equality of people. “... Not a single national culture can serve as a model for other cultures, neither can it be considered modern if it is tightly closed off from them"'. That is why multiculturalism as a form of coexistence of various cultures and their media in one society, in a single legal socio-cultural space, as a form of solving the national problem in a culture aimed at preserving cultural differences and traditions, proves to be unproductive and may sometimes provoke new conflicts. Cultural identity in modern multicultural society should not be based on obligatory prescriptions which regulate life of an individual in a certain community; it should be based on the freedom of cultural choice that does not infringe the freedom of choice of others. Of course, this does not exclude the right of every person or ethnic group to free cultural identity. It is highly important that the realization of this right should not be dictated by misinterpreted ethnic solidarity or ideological pressure on the part of a state or a certain group; it should be determined by an individual's choice. Otherwise, when ideas of artificial state-supported preservation of cultural values oppose the ideas of equal participation of all members of society (irrespective of their ethnicity) in public life, the foundations of sustainable development and democracy are ruined.

Thus, the algorithm of the democratic and egalitarian policy means not only the preservation of cultural diversity but also an increase in participation of people in the process of intercultural interaction, which ensures the emergence of new cultural groups and their incorporation in civic society. Evidently, this algorithm itself should become the strategy of a modern state in respect to its own culture. The principal novelty of the algorithm is the anthropological key to understanding the identity strategies and the harmonious balance of the components of the formula "world unity and cultural diversity", which presupposes the formation of special, dialogic thinking.

7 V. Mezhuyev: Dialog yak sposib mizhkulturnogo spilkuvannya v suchasnomu sviti. “Filosofs'ka Dumka” 2011, No. 4, p. 98. 


\section{Architectonics of the new model of multicultural education under the conditions of social transformations}

Despite the importance of the problem and its certain aspects, there is no coherent concept of multicultural education in the world of pedagogical theory and practice. Sanjin Dragojević, a specialist in Croatian culture studies, summarising the achievements of the research into the issues of intercultural interaction between the members of educational process, argues that in the world today there are at least four basic concepts of multicultural education:

- multicultural education which is focused not on intercultural exchange and mutual interaction but on culture preservation of the existing ethnic minorities,

- intercultural education which is aimed at ensuring an active, positive dialogue of cultures and their mutual understanding and enrichment,

- trans-cultural education which is focused on the system of values formed at the supranational (transnational) level,

- cultural and pluralistic education, the core idea of which is respect and support for all existing cultural needs and lifestyles existing in society (not only ethnic, linguistic, or religious cultures, but also sexual subcultures, peasant subcultures, etc. $)^{8}$.

Despite the differences in the focus of these concepts on their way to pursuing the same strategic goals ('world unity and culture diversity'), each of them necessarily correlates cultural identity with national identity. There the nation falls into a snare of transnationalism or ultranationalism, and the culture faces the situation of multiculturalism which causes limitations of these concepts as well as the concern and anxiety in people. What escapes their attention is that identity today is characterized by considerable dynamics, plurality and contextuality. It is not taken into consideration that identity is not a quality which is inherent in people from birth, this is a processuality and freedom of individual choice. This means that the concept of multicultural education can succeed only when it is based on the implementation of the ideas of respect to each individual as self-value. Global culture and the culture of tribalism whose conceptual principles serve as a basis for the exist-

8 P. Yu. Saukh, Yu. P. Saukh: Mul'tikulturalizm: blesk teorii i prakticheskaya nesostoyatel'nost' proekta $v$ diskurse real'nych processov mezhkulturnogo vzaimodeystviya. "Evraziystvo i Mir" 2014, No. 3, p. 41. 
ing concepts cannot overcome the dislike for otherness because they do not manifest the value of an individual as the highest earthly value. "Globalism and tribalism," as Benjamin Barber rightly states, "are tearing the modern world apart"

In this situation, the architectonics of multicultural education should be built on the cultural and anthropological matrix which guides the educational process towards the dialogue with the culture of a person as its creator and subject capable of cultural self-development. The modern individual is at the border of cultures, the interaction with them requires dialogical communication, understanding and respect for the cultural identity of other people. This is not about ethnic groups, nations or religions, but about their particular representatives. It is quite understandable that these are not nations that make friends, but people who represent these nations. In other words, the architectonics of multicultural education should be aimed at a person and focused on culture. Its goal is a person who explores and creates their own cultural world through the dialogue with the internal and external cultural environment. Intercultural communication built on this life-giving basis results in a special communication field of semantic overlap. What is shown in the process of communication with the Others and their culture is the interaction of the individual with certain social roles, values, norms and customs, attitudes and expectations which the person has to choose and reproduce to reach identity in the difficult process of mutual recognition. The social stock of knowledge gained by a person in the process of intercultural communication not only acts as a prerequisite for accepting and understanding the Others, communicating with them, but also places at their disposal the typing schemes required in most of daily affairs, and as a result, causes the formation of their personal 'Self' based on the balance between the individual and civic identity. Definitely, this by no means distorts the national identity.

This means that the architectonics of multicultural education should be based, firstly, on the principles of dialogic communication, openness and tolerance. Today, people should be taught to appreciate the diversity of cultures through the dialogue rather than synthesis in which there is a hidden danger of losing opportunities for their further development. Above all, it is through dialogue that the opportunity is created to establish a real reciprocity and avoid 'domination - submission' (J. Derrida), the negative consequences of

9 B. R. Barber: Jihad vs. McWord: How Globalism and Tribalism are Reshaping the World. New York 1996, Ballantine Books, p. 332. 
which are so evident today. Secondly, it has to rely on the principle of personality-centredness which focuses not on artificial preservation of the way of life of a nation, but on giving each individual (not just people in general) the right to free cultural self-determination. Culture will be developing in the direction of individual rather than national differences and features that feed the cultural heritage of all nations. No matter how much anybody may want racial, cultural or religious 'purity' today, humanity is destined to live in 'the common house' in the future, having laid the foundations for life-giving intercultural coexistence.

In order to be life-giving, the architectonics of multicultural education should be built, in my opinion, on the following (at least five) important methodological principles. First of all, it is reliance on nation consolidating values. The understanding of values by different ethnic groups may vary, often quite significantly. In spiritual matters, however, there are always values significant for everybody that not only do not cause controversy between representatives of different nationalities, but also find understanding and support among them. These nation consolidating values should be the ones that determine general cultural values for the majority of people, for instance, aversion to lack of freedom, protection of dignity and rights of every person, desire for self-fulfillment, etc. (which, by the way, are not amenable to time erosion). Only on this basis, mechanisms of the semantic augmentation, mutual exchange of values and mutual understanding can be built. The ability of humanity to become a truly human community, united not only by common global threats, but also by joint actions and the common semantic field, which could be called a global outlook, depends on the effectiveness of their implementation.

The second methodological principle of multicultural education should become the critical and analytical attitude to the cultural and historical memory as a representation of reality. Culture as the world of our existence is permeated with memory, which is entwined with the modern era. Any sociocultural transformation (such as is experienced today) is associated with the reference to the past. Each reference enriches the present, in its own way understands it, forming the necessary basis for moving forward. Retrospections of each nation, if they were not caused by the desire to separate from other people and their cultural experience, were fruitful in the reasons they enriched, diversified and expanded their cultural horizons. However, it should not be forgotten that a non-critical and selective look into the depths of history often negatively affects the process of cross-cultural interaction, it 
'creates conditions for deformations of historical memory and the temptation of the corresponding national and cultural obliquity. ${ }^{10}$ The obsession with the past, its idealization, an attempt to build a 'Future-in-the-Past' lifestyle is a dangerous political and cultural strategy.

The third valuable methodological principle of multicultural education should be eradication of cultural and ethnic narcissism which determines cultural and educational isolation. Unfortunately, most of the concepts of multicultural education are situated in western political correctness, of which the conservation of the 'colonial viewpoint of white majority'11 is typical. It seems to me that this political correctness bears very repressive dominance and imposes certain standards. The key metaphor of these standards is nothing but the metaphor of minorities, as though minorities were admired. This admiration is the preservation, it is closely related to narcissism. A narcissus does not see the other, there are only their projections, the projections of their own culture. In the effective educational interaction, it is important to understand, see and hear not the minority member but the other. If the other is not seen, the conditions for producing the centre and the periphery are cultivated. On this basis, there cannot be any effective multicultural education. Today the Other so far not dominant or marginalized cultures strive for the equal place at the round table of the world. They are ambitious and dynamic, with a strong sense of dignity and self-esteem. Despite the fact that different cultures vary by levels of influence, none of them wants to be just tolerated. All cultures consider its basic values to be universal (if it ceases to do so, it will disappear as an independent culture!). They want to be considered. Tolerance is certainly a value, but an intermediate one. Nobody would like to be merely 'tolerated'12. Therefore, these other cultures do not accept and cannot accept the so-called 'positive discrimination' (i.e. the efforts to create certain benefits and preferences for peripheral cultures). These multicultural practices aiming at the restoration of social justice, do not only hinder intercultural understanding, but also distort the global context for the development of educational strategies.

10 P. Yu. Saukh: Suchasna osvita: portret bez prykras. Zhytomyr 2012, ZhDU im. I. Franka, p. 140.

11 V. Makbrayd: Vykladannya sotsial'noyi ta politychnoyi filosofiyi z tochky zoru zachidnoyi i nezachidnoyi perspektyv. "Filosofia Osvity" 2011, No. 1-2, p. 12.

12 P. Yu. Saukh: Suchasni vyklyky globalizovanoyi epokhy: suspil'stvo i tserkva v poshukakh vidpovidey. Ukrayina i Vatikan: do i pislya Drugogo Vatikan'skogo Soboru. Kyyiv 2013, UAR, p. 21 
The fourth methodological principle of multicultural education with its emphasis on cultural differences and increased cultural sensitivity should be the individualization of education. Under this condition, education appears to be the state of open opportunities for self-fulfilment. In modern education, all participants of the educational process - teachers, pupils and students should become 'transgressors'. The act of transgression means overcoming the borders between the possible and impossible, going beyond their cultural and semantic field, and thus getting closer to understanding the Other. As the result of transgression, common cognitive fields are established, where there is mutual understanding, the redefinition of signs, demystification of stereotypes and formation of tolerance zones.

Finally, the fifth fundamental principle of multicultural education is the combination of theory and practice. The link between multicultural education projects and the state policy is very important for ensuring equality and fairness for different groups of people. Instead of pretending that education is isolated from politics, multicultural education should combine learning materials and processes with the imperatives of a democratic society. It can be successful only when it expands rights and opportunities of people and transforms the society. Participation of the actors of the multicultural education process in social movements, voluntary associations, non-government organisations helps to understand oneself and the Other better, to look at things through the eyes of other people. Combining theory with practice, knowledge with actions, provides an opportunity to experience the influence of society on people and feel the relations between such cultural identifiers as race, ethnicity, religion, gender, sexual orientation, social class, language, (dis)ability, age, and many others in real life.

The main strategic guidelines for multicultural education should be: (a) education towards national awareness on the grounds of cultural pluralism which needs people "to think globally, to act locally"; (b) education of the culture of international communication by involving an individual as a subject of intercultural communication in various kinds of culture-generating activity; (c) education of intercultural sociability of an individual. The concept of multicultural education, which is built on a viable imperative (gratitude to the past, action to the present, responsibility to the future), should be aimed at the formation of a global outlook through the awareness of being part of the ethnic group, the state and humanity as a whole by freedom, tolerance, recognition of the value of diversity, solidarity, and non-violence. 
Of course, this concept may become a real policy in the sphere of education under the conditions of: (1) the corresponding cultural policy of the state promoting support for cultural identity of each and every person, which enables the full development of individuals, their dignity in the context of life-giving forces of culture of their people; (2) improving the curricula for primary, secondary and higher education and introducing such courses as intercultural communication, ethno-psychology, critical pedagogy, civic education, ethnology, etc.; (3) writing new course books and improving the existing ones, excluding any manifestations of propaganda of national or cultural superiority and incitement to xenophobia; introducing new teaching methods which are based on practice-oriented activities (information elicitation activities, regulatory and motivational activities, cultural role plays, intercultural partnership activities, etc.).

\section{Experiences and issues of the implementation of the multicultural education project in Ukraine}

The problems of multiculturalism and the implementation of multicultural political projects which form the global context for the development of modern educational strategies are particularly relevant for Ukraine. The reason is simple. Ukraine is a multi-ethnic, multi-religious, multilingual and multicultural country which is closely related to the intensive development of global integration processes. The representatives of more than 130 nations and nationalities that have their own cultural traditions, national identity and religions live here. Furthermore, in Ukraine, as well as worldwide, there is a widely-spread process of identification mechanisms which is getting more and more complicated. National identity now coexists here with professional, gender, religious and regional identities that are often hardly compatible with the former. Most significantly, ethnic groups that previously have not had a chance to be seen and heard, enter the Ukrainian socio-cultural arena. Their identity becomes valuable and, therefore, it appears to be a cultural resource for society, which is to be considered by the state.

Yet, in spite of this and the current tragic situation in Ukraine, the issue of multicultural policy in public and scholarly discussions is scarcely debated. The attention of the political and cultural elite is concentrated on the problems of the state and nation building; within this context, multiculturalism is very often seen as a minor or even disappointing factor that complicates the understanding of the modern Ukrainian national statehood. Under the 
present conditions, Ukrainian society shows the unwillingness to implement a multicultural model of nation building.

The theoretical results in the field of multicultural education, which in some cases are put into practice, mainly gravitate to the so-called intercultural concept where cultural is understood as ethnic and the ethnic model is based on the essentialist view (the idea of a concentrated solution). As a result, cultural boundaries between the groups leave no doubt and the differences are rigidly fixed and over-emphasised, paving the way to xenophobia. Every single ethno-cultural group is attributed non-existent homogeneity, autonomous subjectivity within which the subjectivity of the individual is levelled, causing de-individualisation and leading to human rights violation in practice. Hence, dogma-demand 'Think Ukrainian', which actually prohibits thinking differently, transcending native, cosy, good home culture, exposing it to reflection. On this basis, it is impossible to form a trans-cultural space where people, freed from 'the captivity' of native culture, are ready to meet with another potential 'Self'. Under this condition, a different culture can be perceived as a certain possibility of their own culture. After all, when the own different abilities are included into the communication space, it becomes a transcultural, structural and communicative space for future creation, but not the preservation of multicultural differences or simply a tolerant attitude to differences.

The absence of a clearly defined concept of multicultural education in Ukraine, the attraction to the intercultural policy whose goal is (with the help of the state) simple assimilation of cultural features and traditions of minor ethnical groups, actually governs their lives, limits their right to wider cultural self-determination. Therefore, Ukraine turned out to be outside of the 'politics of recognition' (Charles Taylor), which is the result of the transition from a hierarchical society to a society dominated by the principle of free citizenship as a regulative ideal. The principle of self-preservation of any national culture and humanity in general, lies in an individual's self-transformation. This is not even about universal human values, but of humanism in itself, which implies respect, trust and love. Values of all ideologies, political doctrines, and even religions are ultimately relative. Only the value of life is not relative. Only in connection with this fundamental value they get validity for each personality, only through its mediation they can be experienced and perceived by a human being.

Multicultural education as a social innovation should be linked with the answer to the question 'Who and what should we become?' rather than 
questions 'Who are we?' or 'Where did we come from?' The practical implementation of this project is possible through the democratic and egalitarian policy that not only defends the preservation of cultural diversity via state intervention, but also maximizes people's participation in the processes of intercultural dialogue and communication. Only this approach can incorporate all socio-cultural groups into the civil society as it is a serious obstacle for cultural nationalism which absolutizes differences, and for cultural imperialism which ignores them.

\section{Bibliography}

Barber B. R.: Jihad vs. McWord: How Globalism and Tribalism are Reshaping the World. New York 1996, Ballantine Books.

Bodriyar Zh.: Obshchestvo potrebleniya. Moskva 2006, "Respublika".

International Dictionary of Education. Vol. 7. Oxford 1994, Oxford University Press.

Makbrayd V.: Vykladannya sotsial'noyi ta politychnoyi filosofiyi z tochky zoru zachidnoyi i nezachidnoyi perspektyv. "Filosofia Osvity" 2011, No. 1-2.

Malakhov V:: Natsional'na derzhava, natsional'na kultura $i$ kulturniy suverenitet. "Filosofs'ka Dumka" 2011, No. 4.

Mezhuyev V.: Dialog yak sposib mizhkulturnogo spilkuvannya $v$ suchasnomu sviti. "Filosofs'ka Dumka" 2011, No. 4.

Saukh P. Yu.: Suchasna osvita: portret bez prykras. Zhytomyr 2012, ZhDU im. I. Franka.

Saukh P. Yu.: Suchasni vyklyky globalizovanoyi epokhy: suspil'stvo i tserkva v poshukakh vidpovidey. Ukrayina i Vatikan: do i pislya Drugogo Vatikan'skogo Soboru. Kyyiv 2013, UAR.

Saukh P. Yu., Saukh Yu. P.: Mul'tikulturalizm: blesk teorii i prakticheskaya nesostoyatel'nost' proekta $v$ diskurse real'nych processov mezhkulturnogo vzaimodeystviya. "Evraziystvo i Mir" 2014, No. 3.

Stevenson N.: Globalization, national cultures and cultural citizenship. "Social. Quart." 1997, Vol. 38, No. 1. 


\title{
The methodological strategy of architectonics of multicultural education in the postmodern era
}

\begin{abstract}
The article presents an attempt to interpret a new pluralistic type of civilization and the features of modern multicultural society in the context of educational space. On this basis, the substitution has been suggested of the concept of multicultural education with the term poli-ethnic education, which aims at harmonizing the relations between ethnic or national communities. Within thier limits, this refers also to different socio-cultural groups, with different cultural (political, regional, sexual, religious, age-related, professional, etc.) identities. A new architectonics of multicultural education is suggested and grounded, with a life-giving personality paradigm in the centre. In this regard, five major methodological principles of multicultural education, which serve as its guidelines and major sources, are justified.

The issues of the implementation of the multicultural education project in Ukraine which inhibit the harmonization of public life and the process of intercultural dialogue and understanding are outlined.
\end{abstract}

Key words: multiculturalism, multicultural education, identity, global locality, cultural and historical memory, cultural and ethnical narcissism, democratic and egalitarian policy 